\title{
Pengaruh Pengetahuan, Religiusitas, dan Halal Terhadap Keputusan Memilih Melalui Attitude dan Brand Trust Pada Bakeri Modern (Studi Kasus 3 Bakeri Top Brand)
}

\author{
Ardani Sahputra, Hanny Nurlatifah \\ Program Studi Manajemen, Fakultas Ekonomi, Universitas Al Azhar Indonesia, Komplek Masjid Agung Al \\ Azhar, Jakarta, 12110 \\ Email: ardanishptr@yahoo.com
}

\begin{abstract}
The purpose of this study was to determine the influence of knowledge, religiosity, and halal against the decision of choosing through attitude and brand trust on the 3 top brand modern bakeries. The sample used was the one who bought the product at one of the three bakeries in the last two months of 100 respondents using purposive sampling method. Data analysis method used is descriptive analysis, correspondence analysis, and path analysis. The results found that (1) knowledge, religiosity, and halal are not significantly influence the attitude of the modern bakery. (2) in the modern bakery Bakeri 1, knowledge significantly influence brand trust, while religiosity and halal are not significantly influence brand trust. In modern bakery Bakeri 2, knowledge and religiosity does not significantly affect brand trust, while halal significantly influence brand trust. In modern bakery Bakeri 3, knowledge and religiusias significantly influence brand trust, while halal not significantly influence brand trust. (3) In the modern bakery Bakeri 1, halal significantly influence the decision to choose, whereas knowledge, religiosity, attitude, and brand trust did not significantly influence the decision to choose. In modern bakery Bakeri 2, attitude, and brand trust significantly influence the decision to choose, whereas knowledge, religiosity, and halal are not significantly influence the decision to choose. In modern bakery Bakeri 3, knowledge significantly influence the decision to choose, while religiosity, halal, attitude, and brand trust did not significantly influence the decision to choose.
\end{abstract}

Keywords: Knowledge, religiosity, Halal, Attitude, Brand Trust, Decision of Choosing, Brand Positioning

\section{PENDAHULUAN}

Bisnis bakery di Indonesia cukup menjanjikan karena persentase permintaan yang terakomodir baru sekitar 60\% sedangkan sisanya belum tergarap produsen. Industri pastry dan bakery di Indonesia masih tertinggal jauh dibandingkan dengan di Negara lain. Misalnya saja dibandingkan dengan Negara kepulauan seperti Taiwan, Taiwan memiliki 6.000 praktisi pastry dan bakery. Sementara jumlah praktisi di Indonesia kurang dari 10.000 padahal luas area dan jumlah penduduk Indonesia lebih besar dari pada Taiwan (www.pinkkorset.com). Bisnis bakery modern, dewasa ini menunjukkan perkembangan yang relative pesat, terbukti semakin banyaknya perusahaan bakery asing yang merambah Indonesia.
Berdasarkan data Top Brand Award dari tahun 2013 sampai dengan 2016 dapat dilihat bagaimana bakery modern sangat mendominasi dalam pasar Indonesia. Beberapa alasan masyarakat lebih memilih untuk membeli produk bakery modern adalah karena bakery modern memiliki daya tarik sendiri, dengan banyaknya varian rasa dan keunikan pada produk-produknya. Ditambah lagi dengan jangkauan konsumen akan produk yang diinginkan terbilang mudah. Hal ini disebabkan oleh gerai atau toko bakery modern sudah tersebar di wilayah padat penduduk. Contohnya seperti toko bakery modern yang dibahas pada penelitian ini tersebar di wilayah Jakarta, Bogor, Depok, Tangerang, dan Bekasi (JABODETABEK). Selain dari kemudahan tersebut terdapat faktor yang menjadi preferensi masyarakat untuk membeli produk bakery modern yaitu adanya sertifikat halal/label halal yang semestinya tertera atau 
dijelaskan secara lisan maupun tulisan pada toko maupun produknya. Dengan penduduk mayoritas muslim, tentunya hal ini menjadi penting sebab jika tidak tertera, permintaan dari produk tersebut juga secara otomatis akan menurun

Tabel 1 Top Brand Kategori Toko Roti/Bakery

\begin{tabular}{|c|c|c|c|c|c|}
\hline \multicolumn{3}{|c|}{2013} & \multicolumn{3}{|c|}{2014} \\
\hline MEREK & TBI & TOP & MEREK & TBI & TOP \\
\hline Holland Bakery & $31,7 \%$ & TOP & Holland Bakery & $25,0 \%$ & TOP \\
\hline $\begin{array}{l}\text { BreadTalk } \\
\end{array}$ & $21,7 \%$ & TOP & $\begin{array}{l}\text { BreadTalk } \\
\end{array}$ & $23,9 \%$ & TOP \\
\hline Majestyk & $7,4 \%$ & & Majestyk & $5,9 \%$ & \\
\hline Swiss Bakery & $3,7 \%$ & & Swiss Bakery & $3,6 \%$ & \\
\hline Suzzana & $3,3 \%$ & & Roti Boy & $3,0 \%$ & \\
\hline Buana Bakery & $2,7 \%$ & & Buana Bakery & $2,5 \%$ & \\
\hline Roti Boy & $2,6 \%$ & & Virgin & $2,1 \%$ & \\
\hline Kartika Sari & $1,9 \%$ & & Suzzana & $2,1 \%$ & \\
\hline \multicolumn{3}{|c|}{2015} & \multicolumn{3}{|c|}{2016} \\
\hline MEREK & TBI & TOP & MEREK & TBI & TOP \\
\hline Holland Bakery & $27,8 \%$ & TOP & Holland Bakery & $29,8 \%$ & TOP \\
\hline \begin{tabular}{|l|} 
BreadTalk \\
\end{tabular} & $24,1 \%$ & TOP & BreadTalk & $11,7 \%$ & TOP \\
\hline Majestyk & $5,0 \%$ & & Majestyk & $4,3 \%$ & \\
\hline \begin{tabular}{|l|} 
Roti Boy \\
\end{tabular} & $3,6 \%$ & & Swiss Bakery & $2,5 \%$ & \\
\hline Swiss Bakery & $2,7 \%$ & & & & \\
\hline
\end{tabular}

(Sumber: www.topbrand-award.com)

Tabel 2. Bakery dengan Sertifikat Halal 2016

\begin{tabular}{|l|l|l|c|}
\hline No. & \multicolumn{1}{|c|}{ Nama } & \multicolumn{1}{|c|}{ Perusahaan } & No Sertifikat. \\
\hline 1 & Rotiboy & PT. Rotiboy Bakcshoppa Indonesia & 00160068220214 \\
\hline 2 & $\begin{array}{l}\text { Maicstyk Bakery } \\
\text { \& Cake shop }\end{array}$ & PT. Buminda Raya & 00160046091207 \\
\hline 3 & $\begin{array}{l}\text { D'Stupid Baker } \\
\text { \& D'Rotiboda } \\
\text { Restoran }\end{array}$ & PT. Bocuan Gapapa & 00160063710113 \\
\hline 4 & Susan Bakery & Susan Bakery & 00160043440307 \\
\hline
\end{tabular}

(Sumber: www.halalmui.org)

Berdasarkan tabel diatas dapat dilihat bahwa jumlah bakery modern yang saat ini telah memiliki sertifikat halal masih sangat sedikit. Tentunya hal ini akan membuat khawatir masyarakat muslim untuk memilih produk roti yang aman untuk dikonsumsi.

Kesadaran masyarakat tentang kehalalan produk roti sudah semakin meningkat sejalan dengan munculnya isu-isu negatif tentang bakery yang belum memiliki sertifikat halal/label halal. Akan tetapi, kesadaran masyarakat muslim untuk memperhatikan kehalalan bahan yang terkandung dalam produk masih sangat rendah. Kesadaran konsumen yang rendah dengan sendirinya tidak memunculkan tuntutan kepada produsen untuk memperhatikan kehalalan bahan-bahan yang digunakan. Hal ini berkorelasi positif dengan rendahnya minat produsen mendaftarkan produknya untuk mendapatkan Sertifikat Halal, Karena sulitnya mengurus pengajuan perizinan Sertifikasi Halal. Kondisi diatas tentunya menjadikan masyarakat muslim perlu lebih meningkatkan pengetahuan tentang kehalalan bahan makanan agar dapat memilih makanan yang akan dikonsumsi. (www.bangsaonline.com). Untuk itu perlu diketahui beberapa hubungan antara faktor-faktor yang mempengaruhi keputusan konsumen dalam memilih bakery modern sebagai berikut:

1. Untuk megetahui karakteristik responden

2. Untuk mengetahui brand positioning pada bakery modern

3. Untuk mengetahui pengaruh knowledge, religiusitas dan halal terhadap attitude pada bakery modern

4. Untuk mengetahui pengaruh knowledge, religiusitas dan halal terhadap brand trust konsumen bakery modern

5. Untuk mengetahui pengaruh knowledge, religiusitas, halal, attitude, dan brand trust terhadap keputusan memilih pada bakery modern

\section{TINJAUAN PUSTAKA}

\section{Keputusan Pembelian}

Keputusan untuk membeli timbul karena adanya penilaian yang objektif atau dorongan emosi. Menurut Kotler \& Armstrong (2012) menyatakan bahwa, "Purchase decision is the buyer's decision about which brand to purchase" yang artinya bahwa Keputusan pembelian adalah tahap proses keputusan dimana konsumen secara aktual melakukan pembelian produk. Konsumen sebagai pelaku utama dalam proses pembelian selalu menjadi perhatian produsen. Menurut Kotler \& Armstrong (2012) indikator keputusan pembelian adalah:

1. Pengenalan Kebutuhan

2. Pencarian Informasi

3. Evaluasi Alternatif

4. Keputusan Pembelian

5. Perilaku Setelah Pembelian

\section{Brand Trust}


Kepercayaan merek adalah kemampuan merek untuk dipercaya (brand reliability), yang bersumber pada keyakinan konsumen bahwa produk tersebut mampu memenuhi nilai yang dijanjikan dan intensi baik merek (brand intention) yang didasarkan pada keyakinan konsumen bahwa merek tersebut mampu mengutamakan kepentingan konsumen (Ferrinadewi, 2008). Menurut Saldy (2013), indikator brand trust adalah:
1. Kepercayaan
2. Keandalan
3. Keamanan
4. Kejujuran
5. Harapan

\section{Brand Positioning}

Positioning produk merupakan suatu kegiatan dimana perusahaan menciptakan image positif pada suatu brand atau merk tertentu pada produk sehingga membentuk image positif pada benak konsumen pasca penggunaan produk yang dihasilkan perusahaan atau organisasi. Menurut Hasan (2008) "positioning produk adalah penempatan sebuah merek dibagian pasar dimana merek tersebut akan mendapatkan sambutan positif dibandingkan dengan produk-produk saingannya." Menurut Wardhana (2014), indikator brand positioning adalah:

1. Pelayanan

2. Kualitas

3. Varian Menu

4. Suasana

5. Fitur

6. Gaya Hidup

7. Harga

\section{Attitude}

Sikap adalah kecenderungan belajar untuk berperilaku dengan cara yang konsisten atau tidak, sehubungan dengan objek tertentu. (Schiffman \& Kanuk, 2007). Menurut Setiawan (2014), indikator attitude adalah:
1. Afektif
2. Kognitif
3. Behavioral

\section{Kesadaran Halal}

Menurut Ahmad, Abaidah \& Yahya dalam Danang Waskito (2015) kesadaran halal diketahui berdasarkan mengerti tidaknya seorang muslim tentang apa itu halal, mengetahui proses penyembelihan yang benar, dan memprioritaskan makanan halal untuk mereka konsumsi. Menurut Ambali (2014), indikator kesadaran halal adalah:
1. Kesadaran
2. Pengetahuan
3. Kekhawatiran
4. Tindakan

\section{Label Halal}

Menurut Rangkuti (2010), label halal adalah pencantuman tulisan atau pernyataan halal pada kemasan produk untuk menunjukan bahwa produk yang dimaksud berstatus sebagai produk halal. Label halal sebuah produk dapat dicantumkan pada sebuah kemasan apabila produk tersebut telah mendapatkan sertifikat halal oleh BPPOM MUI. Menurut Rambe (2012), indikator label halal adalah:
1. Proses Pembuatan
2. Bahan Baku Utama
3. Bahan Pembantu
4. Efek

\section{Religiusitas}

Religiusitas adalah sistem simbol, sistem keyakinan, sistem nilai, dan sistem perilaku yang terlembagakan, yang semuanya itu berpusat pada persoalan-persoalan yang dihayati sebagai yang paling maknawi (Ultimate Meaning) (Ancok \& Suroso, 2011). Menurut Marliani (2013), indikator religiusitas adalah:
1. Keyakinan
2. Ritualitas
3. Pengalaman
4. Pengetahuan
5. Pengamalan

\section{Knowledge}

Menurut Suhartono dalam Nurjanatun (2012), Pengetahuan adalah sesuatu yang ada secara niscaya pada diri manusia yang keberadaannya diawali dari kecenderungan psikis manusia sebagai bawaan kodrat manusia yaitu dorongan ingin tahu yang berumber dari kehendak atau kemauan. 
Menurut Mendrofa (2012), indikator knowledge adalah:

1. Pengetahuan Produk

2. Perbedaan Produk

3. Informasi Produk

4. Kualitas Produk

\section{METODE PENELITIAN}

Penelitian dimulai pada bulan November 2016 sampai dengan januari 2017. Sampel yang digunakan adalah orang yang membeli produk di salah satu bakery modern kategori Top Brand disebut sebagai Bakeri 1, Bakeri 2, dan Bakeri 3 dalam dua bulan di akhir 2016 sebanyak 100 responden dengan menggunakan metode purposive sampling. Metode analisis data yang digunakan adalah analisis deskriptif (Descriptive Analysis), analisis korespondensi (Correspondence Analysis), dan analisis jalur (Path Analysis).

\section{HASIL DAN PEMBAHASAN}

Responden dari penelitian ini memiliki komposisi yang seimbang untuk karakteristik jenis kelamin yaitu $50 \%$ untuk pria dan $50 \%$ wanita, usia didominasi antara 20-30 tahun sebanyak 65\%, status didominasi dengan responden yang belum menikah sebanyak $63 \%$, pendidikan terakhir didominasi oleh sarjana sebanyak $48 \%$, pekerjaan didominasi pelajar/mahasiswa sebanyak $40 \%$, dan memiliki pengeluaran sebesar diatas 5.000 .000 rupiah (32\%). Untuk lebih lengkapnya bisa dilihat pada tabel dibawah ini

Dapat diketahui Brand Positioning dari masingmasing bakeri modern yang dibahas, bahwa Bakeri 1 memiliki keunggulan pada kenyamanan outlet dan memberikan kesan prestise. Sedangkan Bakeri 2 memiliki keunggulan pada outlet mudah diketahui. Dan yang terakhir pada Bakeri 3 memiliki keunggulan pada produk memiliki rasa yang enak, variasi produk yang beragam, dan memiliki banyak pilihan rasa.
Tabel 3 Karakteristik Responden

\begin{tabular}{|c|c|c|}
\hline Karakteristik Responden & Frekuensi & Persentase \\
\hline \multicolumn{3}{|c|}{$\begin{array}{c}\text { Jenis Kelamin } \\
\end{array}$} \\
\hline Pria & 50 & $50 \%$ \\
\hline Wanita & 50 & $50 \%$ \\
\hline Total & 100 & $100 \%$ \\
\hline \multicolumn{3}{|c|}{ Usia } \\
\hline$<20$ tahun & 14 & $14 \%$ \\
\hline 20 - 30 tahun & 65 & $65 \%$ \\
\hline$>30$ tahun & 21 & $21 \%$ \\
\hline Total & 100 & $100 \%$ \\
\hline \multicolumn{3}{|c|}{ Status } \\
\hline Menikah & 35 & $35 \%$ \\
\hline Belum Menikah & 63 & $63 \%$ \\
\hline Tidak Bersedia Menyebutkan & 2 & $2 \%$ \\
\hline Total & 100 & $100 \%$ \\
\hline \multicolumn{3}{|c|}{ Pendidikan Terakhir } \\
\hline SMP & 0 & $0 \%$ \\
\hline SMA/Sederajat & 43 & $43 \%$ \\
\hline Diploma & 7 & $7 \%$ \\
\hline Sarjana & 48 & $48 \%$ \\
\hline $\mathrm{S} 2 / \mathrm{S} 3$ & 2 & $2 \%$ \\
\hline Total & 100 & $100 \%$ \\
\hline \multicolumn{3}{|c|}{ Pekerjaan } \\
\hline Pelajar/Mahasiswa & 40 & $40 \%$ \\
\hline Ibu Rumah Tangga & 5 & $5 \%$ \\
\hline Karyawan Perusahaan & 39 & $39 \%$ \\
\hline Pegawai Negeri & 10 & $10 \%$ \\
\hline Wiraswasta & 5 & $5 \%$ \\
\hline Lain-lain & 1 & $1 \%$ \\
\hline Total & 100 & $100 \%$ \\
\hline \multicolumn{3}{|c|}{ Pengeluaran } \\
\hline$<1.000 .000$ & 12 & $12 \%$ \\
\hline $1.000 .000-3.000 .000$ & 30 & $30 \%$ \\
\hline $3.000 .000-5.000 .000$ & 26 & $26 \%$ \\
\hline$>5.000 .000$ & 32 & $32 \%$ \\
\hline Total & 100 & $100 \%$ \\
\hline
\end{tabular}

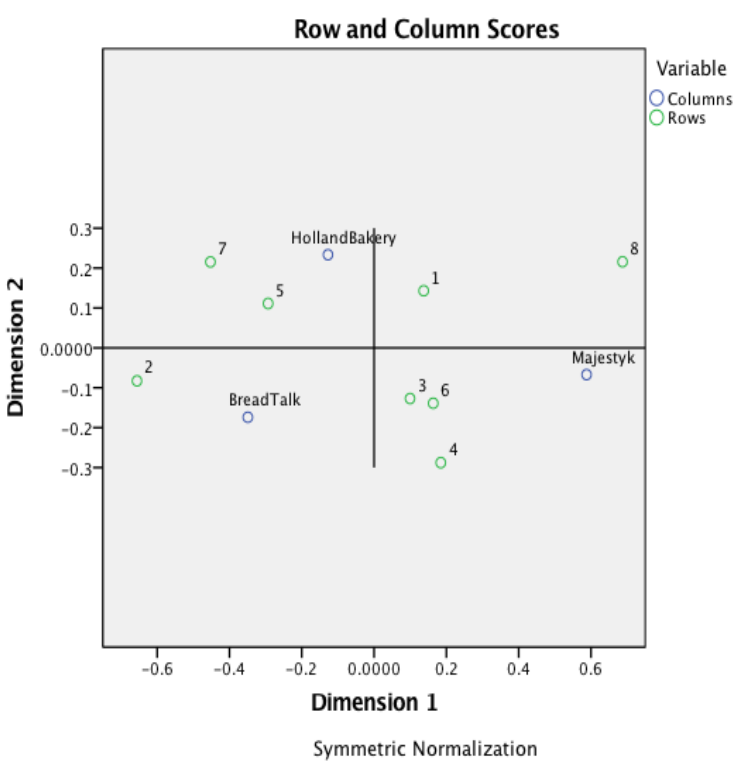

Gambar 1 Diagram CA Penelitian 


\section{Keterangan:}

1. Pelayanan yang diberikan memuaskan

2. Outlet mudah ditemui

3. Produk memiliki rasa yang enak

4. Variasi produk yang beragam

5. Kenyamanan outlet

6. Memiliki banyak pilihan rasa

7. Memberikan kesan prestise

8. Harga yang terjangkau

Pada penelitian ini hubungan antar variabel akan di gambarkan dalam sebuah model diagram jalur yang menggunakan dua variabel independen yang berfungsi sebagai variabel eksogenous dan tiga variabel dependen yang berfungsi sebagai variabel endogenous. Variabel Knowledge, Religiusitas, dan Halal akan berfungsi sebagai variabel eksogenus sedangkan variabel Attitude, Brand Trust, dan Keputusan Memilih berfungsi sebagai variabel endogenus. Model diagram jalur jika diuraikan berdasarkan hubungan antar variabel akan dapat dikelompokkan menjadi tiga bagian atau yang selanjutnya akan disebut Sub Struktur sebagai berikut:

1. Variabel Knowledge, Religiusitas, dan Halal memiliki pengaruh yang signifikan terhadap Attitude.

2. Variabel Knowledge, Religiusitas, dan Halal memiliki pengaruh yang signifikan terhadap Brand Trust.

3. Variabel Knowledge, Religiusitas, Halal, Attitude, dan Brand Trust memiliki pengaruh yang signifikan terhadap Keputusan Memilih.

\section{Bakery 1}

Hasil pengujian respon konsumen terhadap hubungan antar variabel pada bakery modern Bakeri 1 dapat dilihat pada gambar 2 .

Pengaruh langsung atau direct effect akan menunjukkan besarnya pengaruh suatu variabel eksogen terhadap variabel endogennya tanpa melalui variabel lain sebagai perantara. Pada Tabel 4.24 terdapat sebelas hubungan antara variabel eksogen terhadap variabel endogennya. Hubungan antara variabel ini jika dilihat yang memiliki pengaruh secara langsung adalah variabel knowledge $\left(\mathrm{X}_{1}\right)$ dengan brand trust $\left(\mathrm{Y}_{2}\right)$ dan halal $\left(\mathrm{X}_{3}\right)$ terhadap keputusan memilih $\left(\mathrm{Y}_{3}\right)$ dengan pengaruh sebesar 0,549 dan 0,498.

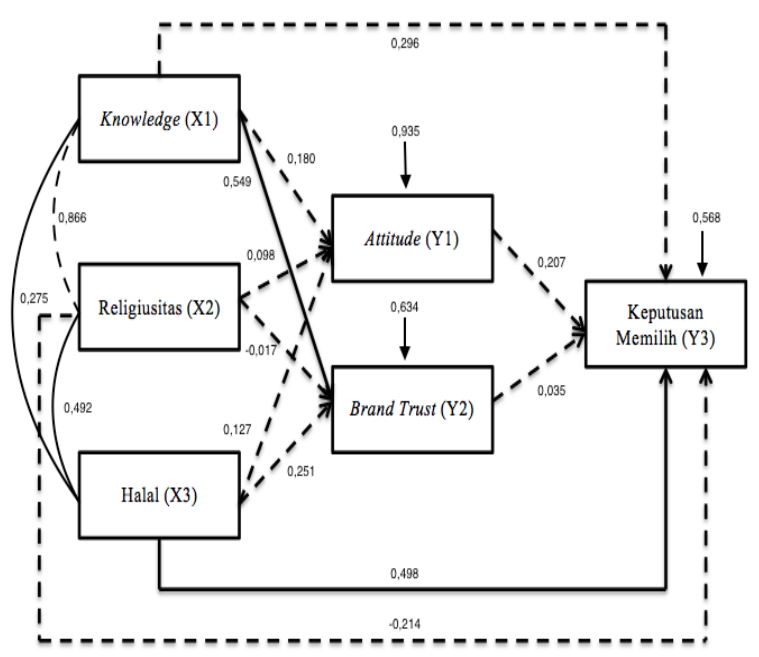

Gambar 2 Diagram Jalur Lengkap Bakery 1

Tabel 4 Hubungan Langsung Antar Variabel Bakery 1

\begin{tabular}{|l|c|l|c|c|}
\hline \multicolumn{3}{|c|}{ Hubungan Langsung Antar Variabel } & Sig. \\
\hline Knowledge & - & Attitude & 0,180 & 0,353 \\
\hline Religiusitas & - & Attitude & 0,098 & 0,629 \\
\hline Halal & - & Attitude & 0,127 & 0,534 \\
\hline Knowledge & - & Brand Trust & 0,549 & 0,002 \\
\hline Religiusitas & - & Brand Trust & $-0,017$ & 0,917 \\
\hline Halal & - & Brand Trust & 0,251 & 0,141 \\
\hline Knowledge & - & Keputusan Memilih & 0,296 & 0,127 \\
\hline Religiusitas & - & Keputusan Memilih & 0,214 & 0,204 \\
\hline Halal & - & Keputusan Memilih & 0,498 & 0,007 \\
\hline Attitude & - & Keputusan Memilih & 0,207 & 0,227 \\
\hline Brand Trust & - & Keputusan Memilih & 0,035 & 0,866 \\
\hline
\end{tabular}

Tabel 5 Hubungan Tidak Langsung dan Hubungan Total Antar Variabel Bakery 1

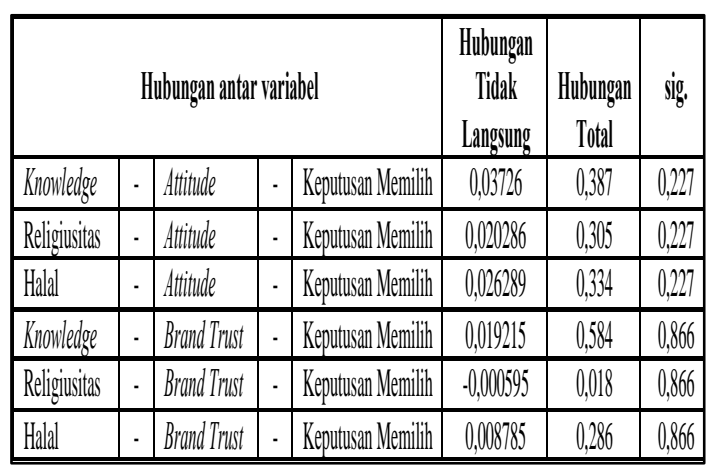

Nilai pengaruh antar variabel secara tidak langsung merupakan nilai yang didapatkan dari 
perkalian antara variabel eksogen dengan variabel perantara hubungan variabel tersebut terhadap variabel endogennya. Pada Tabel 4.25 dapat dilihat bahwa dari enam hubungan tidak langsung, tidak ada satupun variabel yang memiliki hubungan secara tidak langsung.

\section{Bakery 2}

Hasil pengujian respon konsumen terhadap hubungan antar variabel pada Bakery 2 dapat dilihat pada gambar 3 .

Pengaruh langsung atau direct effect akan menunjukkan besarnya pengaruh suatu variabel eksogen terhadap variabel endogennya tanpa melalui variabel lain sebagai perantara. Pada Tabel 4.36 terdapat sebelas hubungan antara variabel eksogen terhadap variabel endogennya. Hubungan antara variabel ini jika dilihat yang memiliki pengaruh secara langsung adalah variabel halal $\left(\mathrm{X}_{1}\right)$ dengan brand trust $\left(\mathrm{Y}_{2}\right)$ sebesar 0,524, attitude (Y1) dengan keputusan memilih (Y3) sebesar 0,320, dan brand trust $\left(\mathrm{Y}_{2}\right)$ terhadap keputusan memilih $\left(\mathrm{Y}_{3}\right)$ dengan pengaruh sebesar 0,433 .

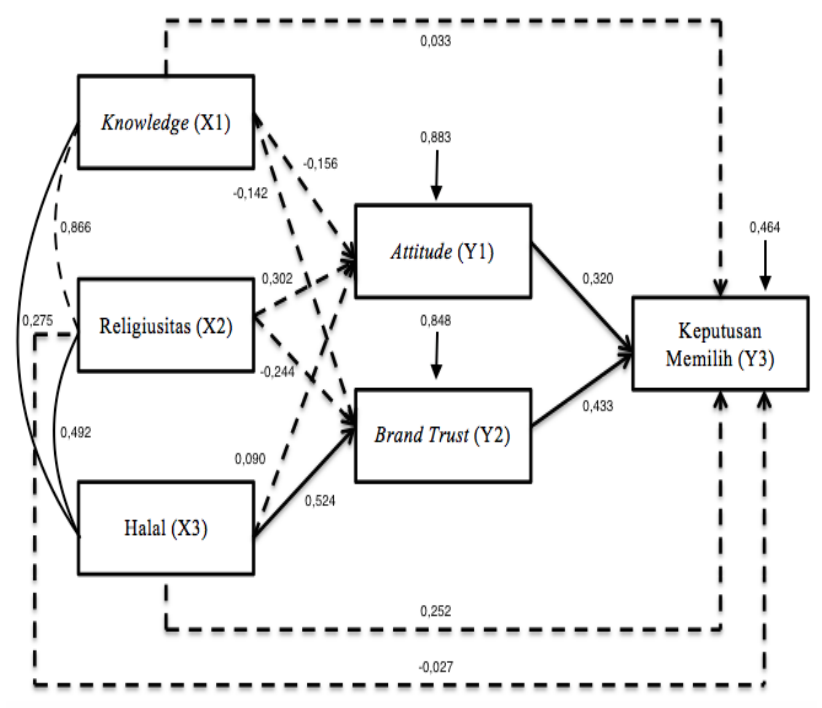

Gambar 3 Diagram Jalur Lengkap Bakery 2

Nilai pengaruh antar variabel secara tidak langsung merupakan nilai yang didapatkan dari perkalian antara variabel eksogen dengan variabel perantara hubungan variabel tersebut terhadap variabel endogennya. Pada Tabel 4.25 dapat dilihat bahwa dari enam hubungan tidak langsung, hanya ada satu yang memiliki pengaruh. Hubungan tersebut adalah variabel halal (X3) terhadap variabel keputusan memilih (Y3) melalui variabel brand trust (Y2) sebesar 0,227.

Tabel 6 Hubungan Langsung Antar Variabel Bakery 2

\begin{tabular}{|c|c|c|c|}
\hline \multicolumn{3}{|c|}{ Hubungan Langsung Antar variabel } & Sig, \\
\hline Knowledge & Attitude & $-0,156$ & 0,378 \\
\hline Religiusitas & Attitude & 0,302 & 0,138 \\
\hline Halal & Attitude & 0,090 & 0,671 \\
\hline Knowledge & Brand Trust & $-0,142$ & 0,412 \\
\hline Religiusitas & Brand Trust & $-0,244$ & 0,218 \\
\hline Halal & Brand Trust & 0,524 & 0,016 \\
\hline Knowledge & Keputusan Memilih & 0,033 & 0,806 \\
\hline Religiusitas & Keputusan Memilih & $-0,027$ & 0,865 \\
\hline Halal & Keputusan Memilith & 0,252 & 0,150 \\
\hline Attitude & Keputusan Memilih & 0,320 & 0,020 \\
\hline Brand Trust & Keputusan Memilih & 0,433 & 0,003 \\
\hline
\end{tabular}

Pengaruh total hubungan antar variabel akan menunjukkan pengaruh variabel eksogen terhadap variabel endogennya. Berdasarkan hubungan antara variabel yang memiliki pengaruh adalah satu jalur hubungan yaitu hubungan antara variabel halal (X3) terhadap variabel keputusan memilih (Y3) melalui variabel brand trust (Y2) sebesar 0,957 .

Tabel 7 Hubungan Tidak Langsung dan Hubungan Total Antar Variabel Bakery 2

\begin{tabular}{|c|c|c|c|c|c|c|}
\hline \multicolumn{4}{|c|}{ Hubungan Antar Variabel } & \multirow{2}{*}{$\begin{array}{l}\text { Hubungan } \\
\text { Tidak } \\
\text { Langoung } \\
0,050\end{array}$} & \multirow{2}{*}{ 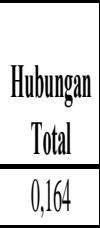 } & \multirow{2}{*}{$\begin{array}{l}\text { Sig, } \\
0,020\end{array}$} \\
\hline Knowledge & Attitude & & Keputusan Memilith & & & \\
\hline Religuintas & Attitude & & Keputusan Memilith & 0,097 & 0,022 & 0,020 \\
\hline Halal & Attitude & & Kepputusan Memilith & 0,029 & 0,41 & 0,020 \\
\hline Knowledge & BrandIrnst & & Keputusann Memilith & 0,061 & 0,291 & 0,003 \\
\hline Religunititas & Brand Irust & & Keputusan Memilith & 0,106 & 0,189 & 0,003 \\
\hline Halal & Brand Irust & & Keputusan Memilith & 0,227 & 0,57 & 0,003 \\
\hline
\end{tabular}

\section{Bakery 3}


Hasil pengujian respon konsumen terhadap hubungan antar variabel pada bakery modern Bakeri 2 dapat dilihat pada gambar 4.

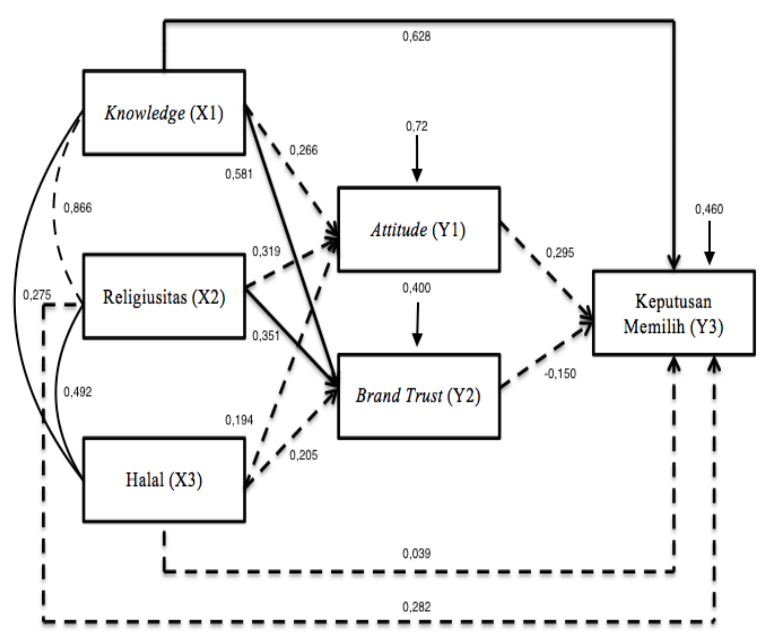

Gambar 4 Diagram Jalur Lengkap Bakery 3

Pengaruh langsung atau direct effect akan menunjukkan besarnya pengaruh suatu variabel eksogen terhadap variabel endogennya tanpa melalui variabel lain sebagai perantara. Pada Tabel 4.48 terdapat sebelas hubungan antara variabel eksogen terhadap variabel endogennya. Hubungan antara variabel ini jika dilihat yang memiliki pengaruh secara langsung adalah variabel knowledge $\left(\mathrm{X}_{1}\right)$ dengan brand trust $\left(\mathrm{Y}_{2}\right)$ sebesar 0,581 , religiusitas $\left(\mathrm{X}_{2}\right)$ terhadap brand trust $\left(\mathrm{Y}_{2}\right)$ sebesar 0,351, dan knowledge (X1) terhadap keputusan memilih (Y3) sebesar 0,628.

Tabel 8 Hubungan Langsung Antar Variabel Bakery 3

\begin{tabular}{|c|c|c|c|}
\hline \multicolumn{3}{|c|}{ Hubungan Langsung Antar Variabel } & Sig. \\
\hline Knowledge & Attitude & 0,266 & 0,224 \\
\hline Religiusitas & Attitude & 0,319 & 0,145 \\
\hline Halal & Attitude & 0,194 & 0,414 \\
\hline Knowledge & Brand Trust & 0,581 & 0,001 \\
\hline Religiusitas & Brand Trust & 0,351 & 0,035 \\
\hline Halal & Brand Trust & 0,205 & 0,250 \\
\hline Knowledge & Keputusan Memilih & 0,628 & 0,009 \\
\hline Religiusitas & Keputusan Memilih & 0,282 & 0,165 \\
\hline Halal & Keputusan Memilih & 0,039 & 0,847 \\
\hline Attitude & Keputusan Memilih & 0,295 & 0,097 \\
\hline Brand Trust & Keputusan Memilih & $-0,150$ & 0,519 \\
\hline
\end{tabular}

Nilai pengaruh antar variabel secara tidak langsung merupakan nilai yang didapatkan dari perkalian antara variabel eksogen dengan variabel perantara hubungan variabel tersebut terhadap variabel endogennya. Pada Tabel 4.49 dapat dilihat bahwa dari enam hubungan tidak langsung, tidak ada satupun variabel yang memiliki hubungan secara tidak langsung.

Tabel 9 Hubungan Tidak Langsung dan Hubungan Total Antar Variabel Bakery 3

\begin{tabular}{|c|c|c|c|c|c|}
\hline \multicolumn{3}{|c|}{ Hubungangantantar Variabel } & $\begin{array}{l}\text { Hubungan } \\
\text { Tidak } \\
\text { Langsung }\end{array}$ & $\begin{array}{c}\text { Hubungan } \\
\text { Total }\end{array}$ & Sig \\
\hline Krowledge & Attitinde & Kepputusan Vemitilih & 0,078 & 0,561 & 0,097 \\
\hline Religunsitas & Attitude & Keputusan Vemitith & 0,094 & 0,014 & 0,097 \\
\hline Halal & Attitude & Kepputusan Memitith & 0,057 & 0,489 & 0,097 \\
\hline Knowledge & Brand IIrsst & Kepoutusan Memilith & $.0,087$ & 0,431 & 0,519 \\
\hline Religunititas & Brand IIrst & Kepoutusan Meminith & $-0,053$ & 0,01 & 0,519 \\
\hline Halal & Brand Trust & Kepulusan Nemitith & $-0,031$ & 0,055 & 0,519 \\
\hline
\end{tabular}

\section{KESIMPULAN}

Berdasarkan hasil analisis data dan pembahasan pada bab sebelumnya, maka dapat diambil kesimpulan sebagai berikut:

Dapat diketahui karakteristik responden dari bakery modern paling banyak responden berusia 20 - 30 tahun, status responden paling banyak masih belum menikah, pendidikan terakhir responden paling banyak sarjana, pekerjaan responden yang paling banyak pelajar/mahasiswa, dan pengeluaran paling banyak responden adalah di atas 5.000.000 perbulan.

Brand Positioning dari Bakeri 1 memiliki keunggulan pada kenyamanan outlet dan memberikan kesan prestise. Bakeri 2 memiliki keunggulan pada outlet mudah ditemui. Dan yang terakhir Bakeri 3 memiliki keunggulan pada produk memiliki rasa yang enak, variasi produk yang beragam, dan memiliki banyak pilihan rasa.

Pada Bakeri 1, knowledge, religiusitas, dan halal tidak berpengaruh secara signifikan terhadap 
attitude. Begitu pula pada Bakeri 2 dan Bakeri 3, knowledge, religiusitas, dan halal tidak berpengaruh secara signifikan terhadap attitude.

Pada Bakeri 1, knowledge berpengaruh secara signifikan terhadap brand trust, sedangkan religiusitas dan halal tidak berpengaruh secara signifikan terhadap brand trust. Pada bakery modern Bakeri 2, knowledge dan religiusitas tidak berpengaruh secara signifikan terhadap brand trust, sedangkan halal berpengaruh secara signifikan pada brand trust. Pada Bakeri 3, knowledge dan religiusitas berpengaruh secara signifikan terhadap brand trust, sedangkan halal tidak berpengaruh secara signifikan terhadap brand trust.

Pada bakeri modern 1, hanya halal yang berpengaruh secara signifikan terhadap keputusan memilih, sedangkan knowledge, religiusitas, attitude, dan brand trust tidak berpengaruh secara signifikan terhadap keputusan memilih. Pada Bakeri modern 2, attitude, dan brand trust berpengaruh secara signifikan terhadap keputusan memilih, sedangkan knowledge, religiusitas, dan halal tidak berpengaruh secara signifikan terhadap keputusan memilih. Pada Bakeri modern 3, hanya knowledge yang berpengaruh secara signifikan terhadap keputusan memilih, sedangkan religiusitas, halal, attitude, dan brand trust tidak berpengaruh secara signifikan terhadap keputusan memilih.

\section{Saran}

Berdasarkan kesimpulan di atas, maka saran dari peneliti adalah sebagai berikut:

1. Bakery modern hendaknya lebih memahami sertifikat halal dan pencantuman label halal pada produknya, walaupun pada penelitian ini halal tidak terlalu berpengaruh secara signifikan. Karena dengan adanya sertifikat halal maupun label halal akan membuat citra perusahaan jadi lebih baik, dan menghindari isu-isu negatif di masa mendatang.

2. Bakery modern yang belum memiliki label halal segera mengurus sertifikat halal dan pencantuman label halal ke LPPOM MUI, karena mayoritas penduduk di Indonesia adalah muslim, maka lebih baik produsen membuat masyarakat menjadi aman dalam mengkonsumsi makanan terutama masyarakat muslim.

\section{DAFTAR PUSTAKA}

Ancok, D \& Suroso, F. N. 2011. Psikologi Islami Solusi Islam Atas Problem-Problem Psikologi. Yogyakarta: Pustaka Pelajar

Ferrinadewi, Erna. 2008. Merek dan Psikologi Konsumen. Yogyakarta: Graha Ilmu

Hasan, Ali. 2008. Marketing. Yogyakarta: Media Utama

Kotler, Philip \& Armstrong, Gary. 2012. PrinsipPrinsip Pemasaran. Jilid 1. Edisi 13. Jakarta: Erlangga

Nurjanatun, D. 2012. Hubungan Tingkat Pengetahuan dan Sikap Wisatawan Terhadap Pemanfaatan Klinik Wisata. Semarang: Universitas Diponegoro

Rangkuti, Freddy. 2010. Analisis SWOT Teknik Membedah Kasus Bisnis. Jakarta: PT. Gramedia Pustaka Utama

Schiffman \& Kanuk. 2007. Perilaku Konsumen. Edisi 2. Jakarta: PT. Indeks Gramedia

Waskito, Danang. 2015. Pengaruh Sertifikasi Halal, Kesadaran Halal, dan Bahan Makanan Terhadap Minat Beli Produk Makanan Halal. Yogyakarta: UNY

http://www.halalmui.org/mui14/index.php/main/go _to_section/56/1362/page/1. Diakses pada tanggal 21 november 2016 